\title{
German Version of the Inventory of Motivations for Hospice Palliative Care Volunteerism: Are There Gender Differences?
}

American Journal of Hospice \& Palliative Medicine ${ }^{\circledR}$ 2018, Vol. 35(2) 304-315 (C) The Author(s) 2017 Reprints and permission: sagepub.com/journalsPermissions.nav DOI: $10.1177 / 1049909117706958$ journals.sagepub.com/home/ajh

(3)SAGE

\author{
Eva-Maria Stelzer, $\mathrm{MSc}^{1,2}{ }^{\oplus}$, Frieder R. Lang, $\mathrm{PhD}^{\prime} \oplus$, Melanie Hörl, MSc', \\ Stefan T. Kamin, PhD', and Stephen Claxton-Oldfield, PhD $^{3}$
}

\begin{abstract}
The present study examined gender differences in motivations for volunteering for hospice using a German version of the Inventory of Motivations for Hospice Palliative Care Volunteerism (IMHPCV). The IMHPCV was translated into German and back-translated into English following the World Health Organization's guidelines for the translation and adaptation of instruments. In an online survey, 599 female and 127 male hospice volunteers from hospice organizations throughout Germany completed the translated version of the IMHPCV, the Scales of the Attitude Structure of Volunteers as well as questions pertaining to their volunteer experience. Based on an exploratory structural equation modeling approach, adequate model fit was found for the expected factor structure of the German version of the IMHPCV. The IMHPCV showed adequate internal consistency and construct validity. Both female and male hospice volunteers found altruistic motives and humanitarian concerns most influential in their decision to volunteer for hospice. Personal gain was least influential. Men rated self-promotion, civic responsibility, and leisure as more important than women. Analyses provided support for the use of the IMHPCV as a measurement tool to assess motivations to volunteer for hospice. Implications for recruitment and retention of hospice volunteers, in particular males, are given.
\end{abstract}

\section{Keywords}

hospice care, palliative care, volunteers, motivation, gender role, patient care

Hospice volunteers play an essential role in providing emotional, social, informational, and instrumental support for both terminally ill patients and their family members at the end of life. Furthermore, they often fulfill administrative tasks within their hospice organization, such as fund-raising or serving on the management board. In Germany, approximately 80,000 individuals volunteer in hospice settings. ${ }^{1}$ German hospice volunteers are predominantly females and 50 years old or older. $^{2}$ Males rarely volunteer for hospice although hospice organizations are desperately trying to recruit them. Similarly, in the United States, Canada, Britain, and New Zealand, less than $20 \%$ of hospice/hospice palliative care (note 1) volunteers are men. ${ }^{3-5}$ Having more male hospice volunteers would be beneficial for both patients and volunteers. For example, male patients or their families may sometimes prefer to be accompanied by a male volunteer rather than a female one. Similarly, volunteers sometimes express preferences regarding who they would like to provide support for (eg, a male or a female patient). However, due to the shortage of male hospice volunteers, hospice coordinators often cannot match volunteers and patients according to their wishes. Why significantly fewer men decide to volunteer for hospice is yet unknown. Understanding the underlying motivations for volunteering in hospice, and men's motives in particular, is essential to answer this question and develop strategies for the recruitment and retention of volunteers.

\section{The Functional Approach to Motivation}

The functional approach of prosocial behaviors seeks to explain individuals' underlying motivations for volunteering. ${ }^{6-8}$ According to this theory, individuals engage in volunteerism to serve certain psychological functions, and they can perform the same volunteer activity to serve different underlying motivational processes. Thus, volunteer work can fulfill one or more distinct psychological functions for individuals at the same time,

\footnotetext{
' Institute of Psychogerontology, University of Erlangen-Nürnberg, Nuremberg, Germany

${ }^{2}$ Department of Psychology, University of Arizona, Tucson, AZ, USA

${ }^{3}$ Department of Psychology, Mount Allison University, Sackville, New Brunswick, Canada

Corresponding Author:

Eva-Maria Stelzer, MSc, Department of Psychology, University of Arizona, I 503 E University Blvd, Tucson, AZ 8572I, USA.

Email: stelzeea@email.arizona.edu
} 
and the same volunteer work can serve different psychological functions at different times in their lives. Clary and colleagues identified and operationalized 6 motivational functions of volunteerism, namely, social bonding, values, influence, learning, career, and self-enhancement. ${ }^{7}$

Motives to volunteer for hospice. Planalp and Trost ${ }^{9}$ asked hospice volunteers to indicate why they started volunteering for hospice using the Volunteer Functions Inventory (VFI), ${ }^{7}$ a 30 -item selfreport measure based on the functionalist approach to volunteering. Volunteers rated "values/understanding" (eg, compassion toward people in need) as the most important motivation for volunteering, followed by "social," "enhancement/ protection," and "career". A more specific approach that was based on the Inventory of Motivations for Hospice Palliative Care Volunteerism (IMHPCV) revealed comparable rank orders of motives. The IMHPCV is a 25 -item self-report instrument specifically designed to study the motivations of hospice palliative care volunteers via 5 subscales. ${ }^{10}$ For example, hospice palliative care volunteers prioritized motives of altruism and of civic responsibility over self-serving motives. ${ }^{10-12}$ In a German study with volunteers, altruistic and humanitarian concerns as well as seeking new learning experiences contributed most strongly to individuals' decision to volunteer for hospice. ${ }^{2}$ Again, in this study, career- and dominance-related motives were ranked least important. Furthermore, German hospice volunteers when compared to nonhospice volunteers reported different reasons for engaging in volunteering. While hospice volunteers rated altruistic concerns for others and new learning experiences as stronger reasons for their service, nonhospice volunteers ranked the importance of self-serving motives of social bonding and achieving influence as higher, suggesting that hospice volunteers are more driven by social agendas while nonhospice volunteers get engaged in more recreational purposes. ${ }^{2}$

Gender differences in the motivation to volunteer. In 2 studies, Claxton-Oldfield and colleagues investigated why relatively few men volunteer for hospice palliative care. ${ }^{3}$ In their studies of middle-aged and older men, less than a quarter expressed an interest in hospice palliative care volunteerism after reading a brief description of typical volunteer tasks although $80 \%$ indicated that they knew about hospice palliative care (study 1). The few men who reported some interest in hospice palliative care volunteerism reported altruistic and humanitarian motives ("I see the need or enjoy helping others"), existing similar volunteer activities ("I already do this kind of work"), and/or self-serving motives ("I might need help myself or would like help for my family"). Reasons reported by those who did not express an interest in volunteering included lack of time, perceived emotional burden, and/or age. In study 2, participants were asked to choose from a list of tasks the ones that they could imagine themselves performing as hospice volunteers. ${ }^{3}$ Males chose most of the social (eg, talk to the patient), practical (eg, drive the patient to the doctor), and emotional support tasks (eg, listening to a patient's life story) and were less interested in administrative tasks (eg, work in the volunteer program's office), tasks that involve direct hands on (physical) patient care/contact (eg, help with feeding), and tasks involving provision of grief and bereavement support. Kolnick and Mulder ${ }^{13}$ conducted focus groups with males in order to develop effective recruitment strategies for male volunteers in a care context. Perceived barriers to volunteerism included fear of failing at an unfamiliar task, disorganized leadership, and unclear expectations set by the organization. ${ }^{13}$ In these focus groups, men associated "terminally ill" patients with "bedridden" and "at death's door," and some men indicated that "care" for someone might be intimidating and contradictory to their self-concept. Studies that included both men and women found no gender differences with regard to ranking of volunteering motives in general, not just among hospice volunteers. ${ }^{14}$ In such studies, values, understanding, and enhancement were prioritized similarly among men and women. Gender differences, however, were found with regard to the overall importance of motives. Women reported higher scores on all motivational functions when compared to their male counterparts. ${ }^{14,15}$ This suggests that women might be more inclined to engage in volunteerism than men. In other studies, men yielded higher scores on instrumental functions, for example, the career motive, while women expressed more altruistic and humanitarian concerns. ${ }^{16,17}$ In summary, although there are few gender differences, men are likely to favor self-serving instrumental motives, whereas women are likely to prioritize altruistic motives and humanitarian concern for others.

\section{Why are Female Volunteers Overrepresented in Hospice and Men in Other Types of Volunteer Work?}

The social role theory of helping views helping as role behavior regulated by social norms that are developed and adopted by men and women in order to conform to social gender role expectations. ${ }^{18,19}$ According to this theory, men are socialized into agentic, heroic, and chivalrous roles from early on, whereas the female gender role fosters communal, nurturing, and caring roles. ${ }^{20,21}$ Thus, with nurturance and care being deeply embedded in the female role definition, women should be more strongly motivated by concern-related motives and therefore more inclined to volunteer for human service delivery and for activities linked to family roles, whereas men rank higher in instrumental functions and should be more likely to engage in a public volunteer domain. ${ }^{21}$ Indeed, a survey among German volunteers ${ }^{22}$ found segregation by sex with regard to areas and activities of volunteering such that women make up the majority of volunteers in social and communal settings including volunteering for kindergarten, in schools, health, and church. Men, in contrast, were more likely to belong to sports and hobby clubs, political and professional organizations, and fire and rescue squads. A similar gender disproportion can be found in hospice settings, with women serving as primary caretakers for individuals who are facing death in both the private (eg, family and friends) and the public sector (eg, nursing homes and hospitals) and both throughout history and across 
cultures. ${ }^{23}$ Furthermore, women were found to score higher on altruistic and humanitarian motives such as "feeling needed," moral obligation, and prosocial role identity compared to men who yielded higher scores on personal gain functions and viewed volunteering as an instrumental tool to achieve their other purposes. ${ }^{14,16,17,24}$

\section{The Present Study}

Despite the apparent gender imbalance among hospice volunteers and the need for more male hospice volunteers in order to meet patients', families', and volunteers' preferences, we are not aware of a study that has systematically investigated gender differences in the hospice volunteer context in a broad and age-heterogeneous sample. Furthermore, there is a general lack of research on German hospice volunteers' reasons for volunteering in hospice. Most studies have been conducted in Canada, the United States, or Great Britain. To our knowledge, no instrument is available in Germany to assess individuals' motivations to volunteer for hospice. Therefore, the current study aims at revealing what motivates both women and men to start volunteering for hospice using a new German translation version of the IMHPCV. Thus, the present study pursued 2 aims: (1) evaluate the psychometric properties of the German-translated IMHPCV in a sample of German hospice volunteers and (2) compare the motives of female and male hospice volunteers.

Our first hypothesis builds on existing literature on motivations of hospice/hospice palliative care volunteers. ${ }^{10-12}$ Based on the findings that hospice/hospice palliative care volunteers are most strongly influenced by altruistic reasons (help those in need) and civic responsibility (desire to give back to the community), whereas instrumental gain reasons, such as "help my career," typically emerge as less influential, we expected German hospice volunteers to score highest on altruism and civic responsibility, followed by leisure, self-promotion, and personal gain.

Our second hypothesis is based on social role theory of helping, ${ }^{18-20}$ and on other prior findings that women's voluntary engagement is primarily driven by altruistic and humanitarian concerns, whereas men place greater value on instrumental motives. ${ }^{16,17}$ Accordingly, we expected women to report greater motivations for altruism and civic responsibility and men to yield higher scores on the self-serving motives of personal gain, self-promotion, and leisure.

\section{Method}

\section{Recruitment and Selection of Study Participants}

We applied a convenience and snowballing framework to recruit active hospice volunteers. We e-mailed a link to an online survey to coordinators of different hospice organizations in Germany, which 2 of the authors (ES and MH) knew personally due to their engagement as hospice volunteers. Coordinators were asked to share the survey link with their active hospice volunteers who have direct patient contact and other coordinators and organizations. Hospice organizations in Germany are nonprofit organizations that vary in size, curriculum of hospice training, and services provided. It is the task of hospice organizations to provide volunteers with training and continuing education opportunities to ensure volunteers are qualified and prepared for their engagement. Once trained, volunteers can decide whether they would like to volunteer in local hospitals, hospices, or people's homes and/or engage in organizational tasks, such as fund-raising. Recruitment lasted from May to August 2015. We obtained responses from hospice volunteers throughout Germany (see Table 1).

Inclusion and exclusion of participants. Initially, 1786 individuals accessed the online survey. Only complete, interpretable, and plausible data sets were included in the analysis. See Figure 1 for a detailed overview of participant enrollment.

\section{Translation}

Based on the guidelines for the translation and adaptation of instruments by the World Health Organization, ${ }^{25}$ we translated the IMHPCV. Figure 2 shows the translation process of the IMHPCV. Table 2 shows the translated IMHPCV (Inventar zu Motiven der ehrenamtlichen Hospiz- und Palliativarbeit).

\section{Measures}

For ease of distribution, we created an online survey using the German online survey software Unipark. ${ }^{26}$ The online survey comprised 4 parts. Part 1 contained information on the study, its aims, design, anonymity, and investigators. Part 2 assessed motivations for volunteering (IMHPCV, Scales of the Attitude Structure of Volunteers [SEEH]). Part 3 comprised questions about their volunteer activity. And part 4 contained demographics.

Inventory of Motivations for Hospice Palliative Care VolunteerismGerman version. The IMHPCV is a 25 -item self-report questionnaire that assesses individuals' motivations for becoming a hospice palliative care volunteer. ${ }^{10}$ The 25 items cover the following 5 conceptually distinct subscales (or categories of motives): altruism (eg, I want to help others cope with death and dying), civic responsibility (eg, I believe that people should give back to their communities), self-promotion (eg, I like the attention I get when volunteering), leisure (eg, I enjoy having something to do with my time), and personal gain (eg, The experience of volunteering would help me with my future goals). Items are rated on a 5-point Likert-type scale from 1 ("did not influence me at all") to 5 ("influenced me a great deal"). Higher scores indicate a greater influence of the motive on their original decision to volunteer in hospice palliative care.

Scales of the attitude structure of volunteers. The SEEH measures individuals' readiness to contribute to nonprofit organizations. ${ }^{27}$ The SEEH consists of 26 items, which represent 8 attitude dimensions: social attachment, self-experience, self-esteem, social influence, professional balance, career, 
Table I. Characteristics of Volunteers. ${ }^{\text {a }}$

\begin{tabular}{|c|c|c|c|c|}
\hline & Female Volunteers $(\mathrm{n}=599)$ & Male Volunteers $(n=127)$ & Total $(\mathrm{N}=726)$ & $\chi^{2}$ \\
\hline Age & & & & $28.54^{\mathrm{b}}$ \\
\hline Younger than 56 & $302(50.4)$ & $31(24.4)$ & $333(45.9)$ & \\
\hline 56 and older & $297(49.6)$ & $96(75.6)$ & $393(54.1)$ & \\
\hline Marital status ${ }^{c}$ & & & & 4.59 \\
\hline Single & $4 \mid(6.8)$ & $8(6.3)$ & $49(6.7)$ & \\
\hline Married/cohabiting & $384(64.1)$ & $91(71.7)$ & $475(65.4)$ & \\
\hline Divorced & $63(10.5)$ & II (8.7) & $74(10.2)$ & \\
\hline Widowed & $47(7.8)$ & $4(3.1)$ & $51(7.0)$ & \\
\hline Education $^{\text {d }}$ & & & & $20.88^{b}$ \\
\hline Hauptschule (= 8 years of schooling) & $47(7.8)$ & II (8.7) & $58(8.0)$ & \\
\hline Mittlere Reife (= 10 years of schooling) & $192(32.1)$ & $22(17.3)$ & $214(29.5)$ & \\
\hline Abitur Abitur (= equivalent to high school) & $126(21.0)$ & $19(15.0)$ & $145(20.0)$ & \\
\hline College/university & $216(36.1)$ & 71 (55.9) & $287(39.5)$ & \\
\hline Other & II (I.8) & $4(3.1)$ & $15(2.1)$ & \\
\hline Employment status $^{\mathrm{e}}$ & & & & $21.65^{b}$ \\
\hline Employed & $332(55.4)$ & $55(43.3)$ & $387(53.3)$ & \\
\hline Unemployed & $7(1.2)$ & $3(2.4)$ & $10(1.4)$ & \\
\hline Retired & $174(29.0)$ & $61(48.0)$ & $235(32.4)$ & \\
\hline Homemaker & $46(7.7)$ & $2(1.6)$ & $48(6.6)$ & \\
\hline Other & $35(5.8)$ & $6(4.7)$ & $4 \mid(5.6)$ & \\
\hline Religion/spirituality $^{f}$ & & & & 0.22 \\
\hline Religious/spiritual affiliation & $503(84.0)$ & $110(86.6)$ & $613(84.4)$ & \\
\hline Federal state ${ }^{g}$ & & & & $3.84^{\mathrm{h}}$ \\
\hline Southern Germany & $229(38.2)$ & $39(30.7)$ & $268(36.9)$ & \\
\hline \multicolumn{5}{|l|}{ Volunteer setting } \\
\hline Private homes $^{j}$ & $452(75.5)$ & $107(84.3)$ & $559(77.0)$ & $4.40^{\mathrm{h}}$ \\
\hline Hospice $^{k}$ & $208(34.7)$ & $58(45.7)$ & $266(36.6)$ & $5.13^{h}$ \\
\hline Palliative care unit ${ }^{\prime}$ & 197 (32.9) & $53(4 I .7)$ & $250(34.4)$ & 3.74 \\
\hline Hospital $^{m}$ & $232(38.7)$ & $63(49.6)$ & $295(40.6)$ & $6.22^{\mathrm{h}}$ \\
\hline Nursing/retirement home ${ }^{n}$ & 449 (75.0) & $96(75.6)$ & $545(75.1)$ & 0.00 \\
\hline Children/adolescents $^{\circ}$ & $61(10.2)$ & $12(9.4)$ & $73(10.1)$ & 0.10 \\
\hline Bereavement support ${ }^{P}$ & $265(44.2)$ & $49(38.6)$ & $314(43.3)$ & 1.60 \\
\hline Organizational work ${ }^{q}$ & $255(42.6)$ & $65(51.2)$ & $320(44.1)$ & $\mathrm{I} .54$ \\
\hline Other ${ }^{r}$ & $217(36.2)$ & $48(37.8)$ & $265(36.5)$ & 0.00 \\
\hline Time commitment, $\mathrm{h} / \mathrm{mo}^{\mathrm{s}}$ & & & & 4.98 \\
\hline $1-10$ & $328(56.7)$ & $58(45.7)$ & $386(53.2)$ & \\
\hline $11-20$ & $200(34.6)$ & $51(40.2)$ & $251(34.6)$ & \\
\hline$>20$ & $39(6.7)$ & $13(10.2)$ & $52(7.2)$ & \\
\hline
\end{tabular}

$a_{n}(\%)$.

${ }^{\mathrm{b}} \mathrm{P}<.00 \mathrm{l}$.

c535 female volunteers, 649 in total.

${ }^{\mathrm{d}} 592$ female volunteers, 719 in total.

e 594 female volunteers, $72 \mathrm{I}$ in total.

f587 females, 713 in total.

${ }_{5} 56$ females, 642 in total.

${ }^{h} P<.05$.

'Rating, in which settings volunteers were "primarily" versus "rarely/never" engaged over the entire duration of his or her volunteer work.

i55। females, 670 in total.

${ }^{k_{5}} 503$ females, 612 in total.

' 500 females, 607 in total.

$\mathrm{m}_{487}$ females, 590 in total.

n547 females, 664 in total.

${ }^{\circ} 490$ females, 594 in total.

P509 female volunteers, 617 in total.

${ }^{\mathrm{q}}$ For example, public relations, office work, and management board; 504 females, 618 in total.

${ }^{r} 426$ females, 520 in total.

${ }^{\mathrm{s}} 567$ females, 689 in total. 


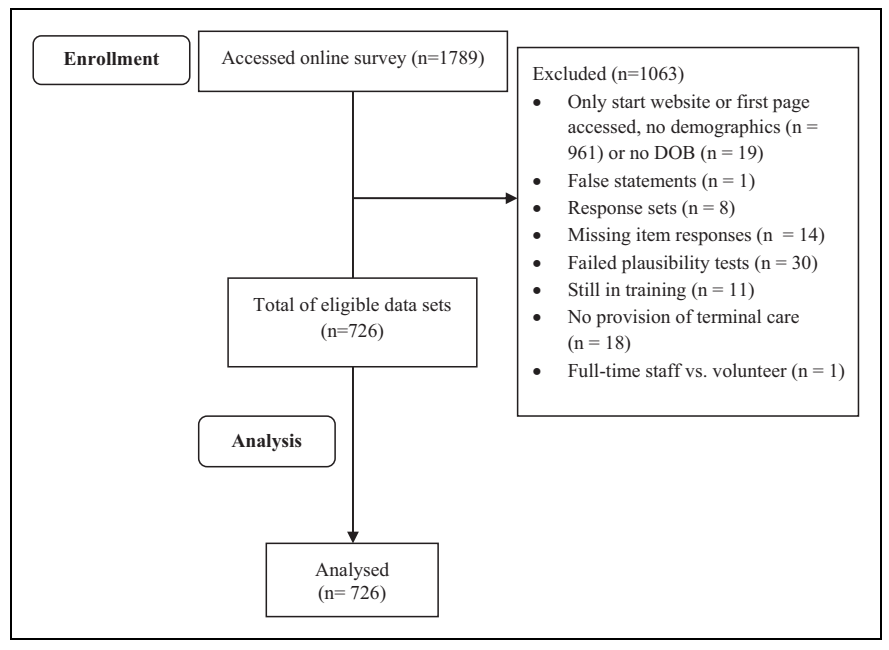

Figure I. Flow chart.

social responsibility, and political responsibility. These attitude dimensions, in turn, can be assigned to 2 higher dimensions, "self-serving" or "altruistic." Respondents were asked to indicate the degree of influence each of the 26 reasons had on their decision to volunteer using a 7-point scale ranging from 1 ("not at all important/accurate for you") to 9 ("extremely important/ accurate for you").

Volunteer activity. Participants were asked to indicate when they had started to volunteer for hospice, the amount of time per month they dedicate to volunteering, to specify the area (direct terminal care: private home, hospice, palliative care unit, hospital, and nursing home, children/adolescents; bereavement support; management board/organization/office work/public relations; and other), and to name their volunteer organization.

Demographics. Participants also reported their gender, age, marital status (single, married and living together, married and not living together, separated/divorced, widowed, and relationship - not married), religion/spirituality (catholic, protestant, other, not religious but spiritual, and none), education (highest completed school/university degree and recoded into years of education), work status (employed full-time, employed parttime, unemployed, retired, homemaker, student, and other), and number of people living in the household.

\section{Procedure of Statistical Analyses}

All statistical analyses were carried out using RStudio ${ }^{28}$ 3.3.1 and Mplus 7.3. ${ }^{29}$ Exploratory structural equation modeling (ESEM), an approach which integrates confirmatory factor analysis and exploratory factor analysis, ${ }^{30}$ was used to assess the structure of the IMHPCV using maximum likelihood estimation with robust standard errors. Exploratory structural equation modeling was specified using oblique rotation, and 5 factors were predefined. In addition, measurement equivalence between female and male volunteers was tested via multigroup comparison. Internal consistency was determined by means of Cronbach $\alpha$. Values between .7 and .9 were considered to indicate good internal consistency. ${ }^{31}$ The SEEH was used as a criterion for testing construct validity. Correlations with results of the SEEH were checked using the hypothesis that another instrument measuring comparable aspects should show high correlation values on the relevant subscales and low correlation values on distinct features. Frequency analyses were run to check for outliers and missing values. When less than $20 \%$ of the items of a scale were missing, values were replaced with the average of sum scale score $(n=10)$. When more than $20 \%$ of the items of a scale were missing, values were replaced with expectation-maximization algorithm $(\mathrm{n}=11)$. We calculated descriptive statistics and ran homogeneity of variances tests for all variables to reflect possible differences in variances. Tests for statistical significance were performed using $\chi^{2}$ tests, $t$ tests, repeated measures multivariate analysis of variance (MANOVA), and multivariate analysis of covariance.

\section{Results}

\section{Description of Study Participants}

Participants were 726 hospice volunteers (599 females and 127 males). Volunteers ranged in age from 16 to 84 years with a mean $(\mathrm{M})$ age of 56.49 (standard deviation $[\mathrm{SD}]=11.19$ ) years. Male volunteers $(M=61.12, S D=12.12)$ were significantly older than female volunteers $(\mathrm{M}=55.51, \mathrm{SD}=10.74)$, $t(724)=5.22 ; P<.001$.

Participants' length of service in hospice ranged from 0 to 30 years with an average of $5.70(\mathrm{SD}=4.95)$ years. Responses of 0 years resulted from volunteers who finished their volunteer training within the last year and therefore have been providing direct terminal care on their own for less than a year. On average, participants volunteered for $12.46(\mathrm{SD}=9.26)$ hours per month. Participants in this study volunteered on average in 3.90 $(\mathrm{SD}=1.83)$ different hospice settings. See Table 1 for characteristics of hospice volunteers.

\section{Factor Structure and Psychometric Properties of the IMHPCV}

Factor structure. Findings from ESEM provided acceptable model fit, $\chi^{2}(185)=460.845, P<.001$; Confirmatory fit index $(\mathrm{CFI})=.933$; root mean square error of approximation $($ RMSEA $)=.045, P=.930(90 \%$ confidence interval $[\mathrm{CI}]=$ $.040-.051)$; standardized root mean square residual $=.029$. Standardized parameter estimates were above .40 on the relevant factors with few exceptions (see Table 3). Parameter estimates on irrelevant factors were generally below .30 . One parameter had a higher loading on the nonrelevant "leisure" component than it did on its intended "self-promotion" factor ("I want to feel better about myself" and "I like being needed"). Three parameters had a higher loading on a nonrelevant (divergent) component than on its intended factor ("I want to feel better about myself," "I like being needed," and "The 


\begin{tabular}{|c|c|c|c|}
\hline Process steps & Performer & Methods & Results \\
\hline $\begin{array}{l}\text { Forward } \\
\text { translations } \\
\text { English } \rightarrow \text { German }\end{array}$ & Two translators ${ }^{\mathrm{a}}$ & $\begin{array}{l}\text { Independent translations of English IMHPCV } \\
\text { (instructions and items) into German }\end{array}$ & $\begin{array}{l}\text { Two } \\
\text { translations }\end{array}$ \\
\hline \multicolumn{4}{|l|}{$\sqrt{ }$} \\
\hline $\begin{array}{l}\text { Comparison of } \\
\text { translations }\end{array}$ & $\begin{array}{l}\text { Coordinator } \\
\text { translation } \\
\text { process }^{\mathrm{d}}\end{array}$ & $\begin{array}{l}\text { Agreements of translations were accepted for } \\
\text { provisional forward translation. Differences in } \\
\text { translations were listed. }\end{array}$ & $\begin{array}{l}\text { Differences } \\
\text { between } \\
\text { translations }\end{array}$ \\
\hline \multicolumn{4}{|l|}{$\sqrt{ }$} \\
\hline $\begin{array}{l}\text { Discussion of } \\
\text { translation } \\
\text { differences }\end{array}$ & $\begin{array}{l}\text { Coordinator of } \\
\text { translation } \\
\text { process }^{\mathrm{d}} \& \text { two } \\
\text { translators }^{\text {a }}\end{array}$ & Possible solutions were discussed and consented & $\begin{array}{l}\text { Single } \\
\text { consented } \\
\text { German } \\
\text { version }\end{array}$ \\
\hline \multicolumn{4}{|l|}{$\sqrt{7}$} \\
\hline $\begin{array}{l}\text { Backward } \\
\text { translation } \\
\text { German } \rightarrow \text { English }\end{array}$ & $\begin{array}{l}\text { Two backward } \\
\text { translators }^{b}\end{array}$ & $\begin{array}{l}\text { Independent backward translations of the } \\
\text { questionnaire without knowledge of the English } \\
\text { original. }\end{array}$ & $\begin{array}{l}\text { Two English } \\
\text { translations }\end{array}$ \\
\hline \multicolumn{4}{|c|}{ 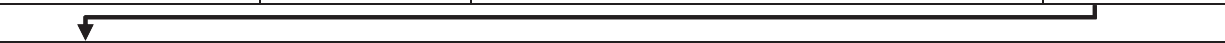 } \\
\hline $\begin{array}{l}\text { Comparison of } \\
\text { English translations } \\
\text { with original } \\
\text { IMHPCV }\end{array}$ & $\begin{array}{l}\text { Author of } \\
\text { original English } \\
\text { instrument: } \\
\text { IMHPCV }^{\mathrm{c}}\end{array}$ & $\begin{array}{l}\text { Each item was rated for its consistency on a scale } \\
\text { of } 1 \text { to } 10 ; 2 \text { items were rated as problematic } \\
\text { items/wording }\end{array}$ & $\begin{array}{l}\text { Problematic } \\
\text { items/wordings } \\
\text { listed for } \\
\text { further } \\
\text { revision }\end{array}$ \\
\hline \multicolumn{4}{|c|}{ ( } \\
\hline $\begin{array}{l}\text { Discussion of } \\
\text { problematic } \\
\text { items/wording }\end{array}$ & $\begin{array}{l}\text { Coordinator of } \\
\text { translation } \\
\text { process }^{\text {d } \& \text { two }} \\
\text { translators }\end{array}$ & Possible solutions were discussed and consented. & $\begin{array}{l}\text { Consented } \\
\text { revised } \\
\text { German } \\
\text { version }\end{array}$ \\
\hline \multicolumn{4}{|l|}{$\checkmark$} \\
\hline Pilot testing & Research Team & $\begin{array}{l}10 \text { hospice volunteers filled out online survey and } \\
\text { gave feedback; problematic items/wording listed }\end{array}$ & $\begin{array}{l}\text { Feedback from } \\
\text { participants } \\
\text { and research } \\
\text { staff }\end{array}$ \\
\hline \multicolumn{4}{|l|}{$\sqrt{5}$} \\
\hline $\begin{array}{l}\text { Adaption according } \\
\text { to pilot testing I }\end{array}$ & $\begin{array}{l}\text { Coordinator of } \\
\text { translation } \\
\text { process }^{\mathrm{d}} \& \text { two } \\
\text { translators }^{\mathrm{a}}\end{array}$ & Possible adaptions were discussed and consented. & Final version \\
\hline
\end{tabular}

Figure 2. Translation process according to guidelines for translation and adaptation of instruments by the World Health Organization.' ${ }^{a}$ German native speakers with high level of fluency and experience in hospice setting in English. ${ }^{b}$ English native speakers with high level of fluency

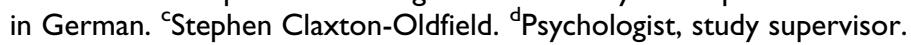

experience of volunteering would help me with my future goals"). Group analyses supported the assumption of equal factor loadings across gender $(\Delta \mathrm{CFI}<.01 ; \Delta \mathrm{RMSEA}<.015)$. Partial support was also found for the equality of item intercepts $(\triangle \mathrm{RMSEA}<.015)$. Such findings indicate that all items measured the latent factors in equivalent ways in males and females (note 2). The intercorrelations of the subscales $(r>.25)$ indicate significant overlap (see Table 4).

Reliability. Table 5 presents the mean, SD, and internal consistency reliability coefficients for the 5 subscales. Good to acceptable internal reliability coefficients $(\alpha \geq .70)$ were found for the subscales civic responsibility, self-promotion, and altruism. Lower coefficients emerged for personal gain and leisure.

Construct validity. The SEEH was used as a criterion for testing construct validity. Construct validity can be assumed for high correlation values $(>.40)$ on conceptually similar IMHPCV and SEEH subscales and no correlation $(<.05)$ between conceptually distinct aspects of the IMHPCV and SEEH subscales. Pearson correlation coefficients showed substantial correlation effects for conceptually similar IMHPCV and SEEH subscales (eg, personal gain and career) and small correlations for conceptually distinct subscales (eg, altruism and enhancement). 
Table 2. Translated IMHPCV Inventory: Inventar zu Motiven der ehrenamtlichen Hospiz- und Palliativarbeit (IMEHPA).

Es gefällt mir, wenn ich etwas in meiner freien Zeit zu 122345 tun habe.

Ich will andere Menschen kennenlernen.

I 2345

Ehrenamtliches Engagement ist ein Hobby für mich.

Ich will etwas tun um mich mit anderen statt mit mir selbst zu beschäftigen.

Ich möchte eine spannende/einbindende Freiwilligenarbeit.

Ich finde Menschen sollten der Gesellschaft etwas geben.

Ich glaube, dass jeder der Gesellschaft etwas zurückgeben sollte.

Allgemein finde ich, dass alle Menschen verpflichtet sind $\quad \begin{array}{lllll}2 & 34 & 4\end{array}$ einen Dienst in ihrer Gemeinde zu leisten.

Ich glaube, dass Freiwilligenarbeit ein notwendiger

Dienst an der Gemeinschaft ist.

Es ist meine Pflicht anderen zu helfen.

Ich will anderen helfen mit Tod und Sterben zurechtzukommen.

Ich will denen helfen, die dem Tod ins Auge sehen.

Ich will helfen den Schmerz lebensbedrohlich erkrankter Menschen zu lindern.

Ich will anderen zu einem glücklichen und angenehmen $\quad \begin{array}{lllll}2 & 3 & 4 & 5\end{array}$ Leben verhelfen, auch im Sterben.

Ich will die Philosophie der Hospiz- und Palliativarbeit $\quad$ I 23345 unterstützen.

Ich will im Gesundheitsbereich arbeiten.

Ich möchte/benötige Erfahrung in einem helfenden Beruf.

Ich will einen "Fuß in die Tür" eines möglichen Berufes I 20345 setzen.

Die Freiwilligenarbeit ist ein notwendiger Bestandteil einer anderen Tätigkeit, der ich nachgehe.

Die Erfahrung des Ehrenamts soll mir helfen meine zukünftigen Ziele zu erreichen.

Ich will einen besseren Eindruck bei meiner Familie, meinen Freunden und in der Gesellschaft machen.

Ich mag die Aufmerksamkeit, die ich bei der Freiwilligenarbeit erhalte.

Ich denke, dass Ehrenamtliche gut angesehen sind.

Ich will zufriedener mit mir selbst sein.

Ich mag es gebraucht zu werden.

Abbreviation: IMHPCV, Inventory of Motivations for Hospice Palliative Care Volunteerism.

Bitte geben Sie an, wie starke der jeweilige Grund Sie beider ursprünglichen Entscheidung beeinflusst hat, sich ehrenamtlich in der Hospiz- und

Palliativarbeit zu engagieren. Bitte verwenden Sie die 5-stufige Skala von I =

"hat mich überhaupt nicht beeinflusst" bis 5 = "hat mich sehr stark beeinflusst."

Pearson bivariate correlations for the IMHPCV and SEEH subscales are presented in Table 4.

\section{What Motivates German Individuals to Volunteer for Hospice?}

Table 5 gives an overview of the means and SD for the IMHPCV and SEEH. Overall, German hospice volunteers rated altruistic motives as most important in their decision to start volunteering, followed by the categories civic responsibility and leisure. Personal gain was the least influential incentive for becoming a hospice volunteer, $\mathrm{V}=0.830, F_{4,722}=$ $879.53, P<.001$.

Similar incentives for the decision to volunteer were reported on the SEEH. The motives understanding and values were rated most influential, followed by work-life balance, personal experiences, political responsibility, social bonding, and enhancement, whereas social influence and career opportunities were rated less influential, $\mathrm{V}=0.871, F_{8,718}=606.90$, $P<.001$.

\section{Do Motivations Differ Between Female and Male Hospice Volunteers?}

For female volunteers, altruism and civic responsibility had the greatest influence on their decision to volunteer, while the selfserving motives like leisure, self-promotion, and personal gain were rated less influential $\left(\mathrm{V}=0.833, F_{4,595}=741.67, P<\right.$ $.001)$. For male hospice volunteers, the rank order was altruism, civic responsibility, leisure, self-promotion, and personal gain $\left(\mathrm{V}=0.826, F_{4,123}=146.35, P<.001\right.$; see Table 5).

A $2 \times 2$ (gender $\times$ age) MANOVA showed no interaction between age and gender, $\mathrm{V}=0.01, F_{5,718}=1.40, P>.05$, on any of the motives. Main effects emerged for gender, $\mathrm{V}=0.03$, $F_{5,719}=4.00, P=.001$, and age, $\mathrm{V}=0.04, F_{5,719}=5.60, P<$ .001 . Test of between-participant effects revealed that gender was significantly related to self-promotion, $F_{1,723}=12.10, P<$ .001 , civic responsibility, $F_{1,723}=9.69, P=.002$, and leisure, $F_{1,723}=5.10, P=.024$. Compared to female hospice volunteers, men yielded significantly higher scores on selfpromotion, civic responsibility, and leisure (see Table 5). Age was significantly related to civic responsibility, $F_{1,723}=12.22$, $P<.001$, and personal gain, $F_{1,723}=6.08, P=.014$. Younger volunteers $(<56$ years) scored significantly lower $(\mathrm{M}=2.95$, $\mathrm{SD}=0.94)$ on civic responsibility than volunteers aged 65 years and older $(\mathrm{M}=3.23, \mathrm{SD}=0.93)$. Younger volunteers scored significantly higher $(\mathrm{M}=1.79, \mathrm{SD}=0.80)$ on personal gain than volunteers aged 56 years and older $(\mathrm{M}=1.66, \mathrm{SD}=$ 0.72 ). The above-reported effects regarding sex and age-group differences remained significant when controlling for the effect of volunteers' experience as measured via length of service.

\section{Discussion}

The present study aimed to investigate the utility of the newly translated version of the IMHPCV in assessing motivations to volunteer for hospice and compared motivations of female and male hospice volunteers in a heterogeneous German sample.

\section{Structure and Psychometric Properties of the IMHPCV}

Objective 1 provided empirical evidence for the reliability and validity of the German version of the IMHPCV in assessing individuals' motivations for becoming a hospice volunteer. In 
Table 3. Standardized Parameter Estimates for the IMHPCV.

\begin{tabular}{|c|c|c|c|c|c|}
\hline & \multicolumn{5}{|c|}{ Factor } \\
\hline & $\mathrm{I}$ & 2 & 3 & 4 & 5 \\
\hline \multicolumn{6}{|l|}{ Leisure } \\
\hline I enjoy having something to do with my time. & .628 & & & & \\
\hline I want to meet other people. & .486 & & & & \\
\hline Volunteering is a hobby for me. & .475 & & & & \\
\hline I want an activity to focus on others instead of myself. & .461 & & & & \\
\hline I want exciting/involving work. & .348 & & & & \\
\hline \multicolumn{6}{|l|}{ Civic responsibility } \\
\hline I believe that people should give back to their communities. & & .841 & & & \\
\hline I believe that everyone should give something back to the community. & & .786 & & & \\
\hline I generally think that people are obligated to provide service to the towns they live in. & & .689 & & & \\
\hline I believe that volunteering is a required part of community service. & & .570 & & & \\
\hline It is my responsibility to help others. & & .438 & & & \\
\hline \multicolumn{6}{|l|}{ Altruism } \\
\hline I want to help others cope with death and dying. & & & .739 & & \\
\hline I want to help those who are facing death. & & & .739 & & \\
\hline I want to help ease the pain of those living with a life-threatening illness. & & & .578 & .205 & \\
\hline I want to make others happy and comfortable in life, as well as in death. & & & .529 & & \\
\hline I want to support the philosophy of palliative care. & & .219 & .229 & & \\
\hline \multicolumn{6}{|l|}{ Personal gain } \\
\hline I want to work in the medical field. & & & & .669 & \\
\hline I want/need experience in a "helping profession." & & & & .594 & \\
\hline I want to get a foot in the door for potential employment. & & & & .581 & \\
\hline Volunteering is a requirement to fulfill my involvement in another activity. & & & & .487 & \\
\hline The experience of volunteering would help me with my future goals. & .285 & & & .279 & \\
\hline \multicolumn{6}{|l|}{ Self-promotion } \\
\hline I want to improve the image I portray to family, friends, and society. & & & & & .808 \\
\hline I like the attention I get when volunteering. & & & & & .702 \\
\hline I think that people tend to look favorably on volunteers. & & & & & .463 \\
\hline I want to feel better about myself. & .494 & .218 & & & .171 \\
\hline I like being needed. & .368 & & & & .264 \\
\hline
\end{tabular}

Abbreviations: ESEM, exploratory structural equation modeling; IMHPCV, inventory of motivations for hospice palliative care volunteerism; ML, maximum likelihood.

${ }^{\mathrm{a}} \mathrm{I}=$ leisure, 2 = civic responsibility, 3 = altruism, 4 = personal gain, 5 = self-promotion; ESEM model with ML estimation and oblique rotation; loadings $\geq .2$. Convergent loadings are printed in bold.

correspondence with the findings by Claxton-Oldfield and colleagues, ${ }^{10}$ ESEM showed that 5 factors may adequately represent individuals' motivations to volunteer for hospice. However, due to fairly low parameter estimates and the cross-loadings of multiple items, the model may benefit from reduction in items. Subscales were internally consistent $(\alpha \geq$ $.70)$ except for personal gain $(\alpha=.68)$ and leisure $(\alpha=.63)$. The low internal consistency for these 2 subscales may result from translation issues of the IMHPCV, which was originally developed for use in predominantly English-speaking countries. Another explanation might be that German hospice volunteers could not relate to items of the personal gain and leisure subscales. Claxton-Oldfield et $\mathrm{al}^{10,12}$ reported higher Cronbach $\alpha$ for the original English scale. In a French validation, ${ }^{11}$ internal consistency reliability coefficients ranged from .10 (personal gain) to .76 (civic responsibility). Substantial overlap was found between the scales leisure and self-promotion. Evidence of the construct validity for the 5 subscales was obtained through significant correlation coefficients for conceptually similar factors of SEEH and IMHPCV, such as high correlations among altruistic and humanitarian concepts and among self-serving functions and nonsignificant correlation coefficients for less conceptually relevant facets of SEEH and IMHPCV, such as between altruistic and self-serving functions.

\section{Motives of German Hospice Volunteers}

Consistent with the existing literature on motivations of hospice volunteers ${ }^{2,9-12}$ and our hypotheses, we found German hospice volunteers to be primarily driven by altruistic and humanitarian concerns, whereas the motives leisure, self-promotion, and personal gain were not as important to hospice volunteers. The same or a similar order of category of motives was reported for Canadian and British hospice/hospice palliative care volunteers with altruism and civic responsibility being rated the most influential category and personal gain being viewed least influential. ${ }^{10,12} \mathrm{~A}$ similar 
Table 4. Correlations between IMHPCV and SEEH Scales. ${ }^{a}$

\begin{tabular}{|c|c|c|c|c|c|c|c|c|c|c|c|c|c|c|}
\hline & $A$ & SP & PG & $C R$ & L & SB & $U$ & V & $E$ & SI & WLB & C & PR & PE \\
\hline$A$ & 1.00 & .149 & .168 & .302 & .139 & .115 & .180 & $.48 I^{b}$ & $.042^{c}$ & .041 & .118 & .092 & .239 & .252 \\
\hline SP & & 1.000 & .359 & .269 & .542 & .409 & .269 & .320 & $.609^{b}$ & .266 & .243 & .149 & .112 & .071 \\
\hline PG & & & 1.000 & .134 & .281 & .351 & .362 & .212 & .367 & .178 & .125 & $.546^{b}$ & .190 & .115 \\
\hline$C R$ & & & & 1.000 & .255 & .101 & .089 & $.527^{b}$ & .051 &.$|4|$ & .088 & $-.022^{c}$ & .237 & $.13 \mid$ \\
\hline $\mathrm{L}$ & & & & & 1.000 & $.482^{\mathrm{b}}$ & .286 & .230 & .354 & .159 & .332 & .099 & .085 & .022 \\
\hline SB & & & & & & 1.000 & .404 & .234 & .437 & .226 & .275 & .257 & .215 & .173 \\
\hline$U$ & & & & & & & 1.000 & .218 & .331 & .127 & .270 & .227 & .189 & .103 \\
\hline $\mathrm{V}$ & & & & & & & & 1.000 & .166 & .130 & .182 & .029 & .265 & .248 \\
\hline$E$ & & & & & & & & & 1.000 & .256 & .264 & .313 & .159 & .052 \\
\hline SI & & & & & & & & & & 1.000 & .111 & .173 & .119 & .093 \\
\hline WLB & & & & & & & & & & & 1.000 & .179 & .056 & .069 \\
\hline C & & & & & & & & & & & & 1.000 & .191 & .121 \\
\hline PR & & & & & & & & & & & & & 1.000 & .279 \\
\hline PE & & & & & & & & & & & & & & 1.000 \\
\hline
\end{tabular}

Abbreviations: IMHPCV: A, altruism; CR, civic responsibility; L, leisure; PG, personal gain; SP, self-promotion. SEEH: E, enhancement; SB, social bonding; SI, social influence; U, understanding; V, values; WLB, work-life balance. C, career; PE, personal experiences; PR, political responsibility. IMEHPA, Inventar zu Motiven der ehrenamtlichen Hospiz- und Palliativarbeit; IMHPCV, Inventory of Motivations for Hospice Palliative Care Volunteerism; SEEH, Scales of the Attitude Structure of Volunteers.

${ }^{\text {a }}$ Correlation coefficients with $P \leq .01$ are shown in bold. Correlation coefficients with $P<.05$ are shown in italics.

${ }^{b}$ Convergent correlations of $>.40$ between IMEHPA and SEEH.

cDivergent correlations of $<.05$.

Table 5. Means (M), Standard Deviations (SD), and Internal Reliability Coefficients (Cronbach $\alpha$ ) for the Scales IMHPCV and SEEH for Female and Male Hospice Volunteers.

\begin{tabular}{|c|c|c|c|c|c|c|}
\hline & \multicolumn{2}{|c|}{ Female Volunteers $(n=599)$} & \multicolumn{2}{|c|}{ Male Volunteers $(n=127)$} & \multicolumn{2}{|c|}{ Total $(\mathrm{N}=726)$} \\
\hline & Mean (SD) & $\alpha$ & Mean (SD) & $\alpha$ & Mean (SD) & $\alpha$ \\
\hline \multicolumn{7}{|l|}{ IMEHPA } \\
\hline Leisure & $2.32(0.8 \mathrm{I})$ & .63 & $2.49(0.8 I)$ & .63 & $2.35(0.82)^{\mathrm{a}}$ & .63 \\
\hline Civic responsibility & $3.05(0.94)$ & .81 & $3.34(0.93)$ & .82 & $3.10(0.94)^{b}$ & .81 \\
\hline Altruism & $3.82(0.8 \mathrm{I})$ & .75 & $3.81(0.80)$ & .75 & $3.82(0.81)$ & .72 \\
\hline Personal gain & I.7I (0.75) & .68 & $1.74(0.80)$ & .71 & $\mathrm{I} .72(0.76)$ & .68 \\
\hline Self-promotion & $1.95(0.70)$ & .69 & $2.19(0.79)$ & .73 & $1.99(0.72)^{b}$ & .70 \\
\hline \multicolumn{7}{|l|}{ SEEH } \\
\hline Social bonding & $2.70(1.40)$ & .82 & $2.75(1.38)$ & .85 & $2.71(1.40)$ & .83 \\
\hline Understanding & $4.87(1.62)$ & .85 & $4.52(1.73)$ & .89 & $4.81(1.64)^{\mathrm{a}}$ & .86 \\
\hline Values & $4.65(1.50)$ & .80 & $4.89(1.44)$ & .80 & $4.70(1.47)$ & .75 \\
\hline Enhancement & $2.08(1.22)$ & .78 & $2.33(1.40)$ & .81 & $2.12(1.26)^{\mathrm{a}}$ & .79 \\
\hline Social influence & $1.52(0.88)$ & .35 & $1.92(1.26)$ & .75 & I.59 $(0.97)^{\mathrm{b}}$ & .43 \\
\hline Work-life balance & $3.84(1.67)$ & .70 & $3.72(1.66)$ & .71 & $3.82(1.67)$ & .70 \\
\hline Career & $1.56(1.12)$ & .81 & $1.39(0.90)$ & .77 & $\mathrm{I} .53(1.08)$ & .81 \\
\hline Political responsibility & $3.29(1.85)$ & .89 & $2.87(1.72)$ & .90 & $3.21(1.83)^{\mathrm{a}}$ & .89 \\
\hline Personal experiences & $3.42(1.68)$ & .70 & $3.07(1.58)$ & .73 & $3.36(1.67)^{\mathrm{a}}$ & .70 \\
\hline
\end{tabular}

Abbreviations: IMEHPA, Inventar zu Motiven der ehrenamtlichen Hospiz- und Palliativarbeit; IMHPCV, Inventory of Motivations for Hospice Palliative Care Volunteerism; SEEH, Scales of the Attitude Structure of Volunteers.

${ }^{\mathrm{a} p}<.05$.

${ }^{\mathrm{b}} \mathrm{P}<.0 \mathrm{0l}$.

rank order was found in a broader and not hospice-related VFI (SEEH). Overall, mean scale scores reported by German hospice volunteers were approximately 2 to 3 points lower compared to mean scores found in the Canadian sample ${ }^{10}$ but surprisingly similar in size to mean scores of the British sample $^{12}$ with one exception (German hospice volunteers scored 4 points lower on the leisure subscale).
In our study, we observed that men and women did not differ in their volunteering motivations related to altruistic and personal gains. However, male hospice volunteers were more likely than women to seek out volunteer experiences in order to stay active (leisure), to feel being needed (self-promotion), and to give back to society (civic responsibility). Although we expected men to score higher on the leisure and self-promotion 
function, we did not anticipate finding stronger civic responsibility motivations for men compared to their female counterparts. Consistent with the social role theory of helping and related research, ${ }^{14,17-20}$ we found that women scored higher on concern-related motives, fulfilling social norms, and gender stereotypical behaviors for women, such as nurturing and caring activities. The greater influence of civic responsibility on men's motivations may reflect their political responsibility and their willingness to engage in the public sector. Men's higher scores on the leisure and selfpromotion motives may reflect an attempt to maintain involvement after exiting the workforce and to stay visible on a societal level during retirement, a transition that may not be as crucial for women due to their higher rates of being homemakers and working part time versus full time. Overall, however, it is important to remember that male hospice volunteers in this study were significantly older than their female counterparts. Research supports that male longevity is associated with the endorsement of less male/macho characteristics. $^{32}$ Over the life course, traditional gender expectations in everyday life may become less important, leading to an integration of feminine and masculine characteristics among older individuals and a "degendering" of men. ${ }^{33}$ Thus, we cannot preclude that male hospice volunteers may endorse different gender roles and attitudes as compared to other men or male nonhospice volunteers. Overall, female and male hospice volunteers seem to be driven by similar motives, a fact that is reflected by the same rank order of motives for female and male hospice volunteers: Altruism and civic responsibility were endorsed as being the most influential, whereas self-enhancing motives were rated less influential.

Age differences in motivations to volunteer emerged for the subscales career and civic responsibility. While the importance of the career motive decreased significantly with age, career-related expectations and motivations appeared to be more important for young individuals as compared to old volunteers. Accordingly, Stelzer and Lang ${ }^{2}$ reported comparable age differences in a cross-national sample of US and German volunteers such that younger volunteers scored significantly higher on career-related motives compared to older volunteers. In addition, in this US-German sample, younger volunteers when compared to their older counterparts rated the SEEH subdimension of enhancement/civic responsibility as more important. Findings of the present study are also in accordance with the socioemotional selectivity theory, ${ }^{34}$ suggesting that as individuals age, they experience a shift in priorities of their social goals, investing in goals and activities related to emotional gratification, whereas knowledge-related goals, such as career advancement, become less important. Thus, older individuals may be more strongly motivated to experience emotionally rewarding relationships and interactions with terminally ill individuals and to give back to society, while younger individuals are driven by future-oriented goals, such as hope for contacts beneficial for their career.

\section{Implications for Future Use of the IMHPCV}

The IMHPCV is a reliable and valid self-report measure that may serve as a tool for hospice organizations to recruit and retain volunteers. The results of this study have important implications for the recruitment of hospice volunteers in general and male ones in particular. Recruitment messages, for example, can be tailored to individuals' motivations in order to match the most influential categories of motives. Building on findings of the present study, recruitment messages should emphasize the opportunity to express altruistic and humanitarian concerns when volunteering for hospice. Recruitment strategies could further be tailored to men or women according to the motives that were found most salient in this study. For women, an effective recruitment message could appeal to their desire to help (altruistic motives) and their perceived responsibility to give back to the community (civic responsibility). A recruitment message for male hospice volunteers could play on men's stronger desire to give back to the community, their wish to make use of their spare/free time, and to feel being needed besides their overarching desire to help others. Based on our research findings, recruitment messages that emphasize altruistic and humanitarian concerns as well as opportunities to fulfill men's motives of leisure and self-promotion should prove most effective in raising the interest of potential male volunteers. Assessing volunteers' motivations allows hospice organizations to match volunteer activities according to volunteers' underlying motivations. This can help increase volunteers' satisfaction, which will, in turn, retain current volunteers and decrease turnover rates. ${ }^{8}$

But where can hospice organizations find potential men who are willing to volunteer for hospice? In the present study, male hospice volunteers were significantly older than female hospice volunteers, suggesting that recruitment efforts targeted at older men may be a first step to overcome the current gender imbalance. Potential volunteer pools to recruit "older men" may include political parties and sport organizations. ${ }^{22}$ Younger male volunteer pools may include college students, health-care organizations, and internship programs. Male hospice volunteers could serve as role models for their male counterparts by sharing their experiences of working with the dying and their families. Overall, men have been found to prefer short-term care concepts, practical tasks, and problemsolving activities over nurturing activities. ${ }^{13}$ The length of volunteer training programs may discourage some men from becoming a hospice volunteer. In Germany, volunteer training programs vary greatly in their length from 2-day long programs to 115 -hour programs. In a study by Kolnick and Mulder, ${ }^{13}$ men indicated that they could imagine volunteering for an average of 4 hours per month. Thus, men's anticipated actual hours of service may not be in relation to the length of the preceding training, which may discourage them from applying in the first place. The volunteer research further suggests that men need specific hooks that could lead them to volunteering. ${ }^{24}$ Moreover, hospice organizations could make use of the Internet, including Facebook, and volunteer portals like "volunteer 
match" or listservs of other institutions to attract potential volunteers. In the United States, more than half of the current volunteers with Internet access indicated that they searched online for volunteer opportunities. ${ }^{35}$ Overall, however, a "personal ask" approach is regarded the most effective recruitment method. ${ }^{36}$

\section{Strengths and Limitations of This Research}

The present study included more than 700 hospice volunteers from different regions in Germany. The high response rate in this study reflected the willingness of hospice coordinators to share the survey link with their hospice volunteers as well as the use of an online survey. However, we cannot preclude that the use of an online survey may have discouraged some possible participants who are less comfortable using a computer to participate in the study. Although the sample may not be representative due to snowball sampling, we argue that participants in this study reflect the heterogeneity of German hospice volunteers. The demographic composition is comparable to that of other studies including Canadian, American, British, and French hospice/hospice palliative care volunteers. ${ }^{10-12}$ Our findings thus shed new light on the gender-related imbalance among hospice volunteers, suggesting that male hospice volunteers are more likely to volunteer for reasons of civic responsibility, self-promotion, and leisure as compared to women.

\section{Future Directions and Outlook}

Given an increasingly aging population, the need for strategies to facilitate the recruitment and retention of hospice volunteers is greater now than ever. The significance of hospice volunteers is further displayed by the average number of hours volunteers contribute per month (12.46), which adds up to approximately 150 hours per year per volunteer. With an average of 50 hospice volunteers per organization, ${ }^{1}$ this corresponds to an added total of 7500 hours of hospice services provided through volunteers per year. Hospice organizations in Germany are nonprofit organizations that rely heavily on the voluntary engagement of individuals in complementing the services and care offered by the interdisciplinary hospice staff. The present study provides valuable insight into the specific motivations that underlie both women's and men's decision to volunteer in hospice. However, many questions still remain unanswered. First, it would be interesting to know what roles and activities male hospice volunteers typically take on in order to tailor recruitment messages accordingly. Furthermore, focus groups with active male hospice volunteers may provide valuable insight why they decided to sign up and what "specific hooks" 24 convinced them to volunteer in hospice. Third, we used a gender framework to explain motivational differences between female and male hospice volunteers. With gender frameworks and social norms being strongly tied to the cultural context, it would be interesting to investigate motives of hospice volunteers in other cultural settings with different gender stereotypes and behaviors. Furthermore, we may expect that prevailing perceptions of hospice volunteers and existing gender norms may affect men's willingness to volunteer for hospice.

The current study provides evidence for the utility of the IMHPCV as an assessment tool of individuals' motivations to start volunteering for hospice. Men's interest, or lack thereof, in volunteering for hospice is an important topic to address. The lack of male volunteers continues to be an issue for hospice volunteer programs. Based on such findings, volunteer coordinators may be able to find new and better ways to attract more men to this volunteer activity.

\section{Authors' Note}

Upon request, data will be made available by the author(s) in accordance with German law for data protection.

\section{Declaration of Conflicting Interests}

The authors declared no potential conflicts of interest with respect to the research, authorship, and/or publication of this article.

\section{Funding}

The authors received no financial support for the research, authorship, and/or publication of this article.

\section{ORCID iD}

Eva-Maria Stelzer, MSc (D) http://orcid.org/0000-0002-3589-8602

Frieder R. Lang, PhD (D http://orcid.org/0000-0002-2660-1619

\section{Notes}

1. In accordance with cultural practice, the term "hospice palliative care volunteers" is used to refer to Canadian volunteers only as well as the IMHPCV; all other volunteers (eg, study participants from Germany, United States, etc) are referred to as "hospice volunteers."

2. For additional information on the measurement equivalence, please contact the authors.

\section{References}

1. Deutscher Hospiz- und PalliativVerband e.V. Palliativ- und Hospizversorgung in Deutschland. Was gibt es und was fehlt?-eine Bestandausfnahme. 2011; http://www.bhpv.de/fileadmin/user_ upload/bhpv/pdf/wissen/evangelische $\% 20$ akademie $\% 20$ tutzing $\%$ 202011.pdf. Accessed April 24, 2017.

2. Stelzer EM, Lang FR. Motivations of German hospice volunteers: how do they compare to nonhospice volunteers and US hospice volunteers? Am J Hosp Palliat Care. 2014; 33(2):154-163.

3. Claxton-Oldfield S, Guigne S, Claxton-Oldfield J. How to attract more males to community-based hospice palliative care volunteer programs. Am J Hosp Palliat Care. 2009;26(6):439-448.

4. Roessler A, Carter H, Campbell L, MacLeod R. Diversity among hospice volunteers: a challenge for the development of a responsive volunteer program. Am J Hosp Palliat Care. 1999;16(5): 656-664.

5. Payne S. Dilemmas in the use of volunteers to provide hospice bereavement support: evidence from New Zealand. Mortality. 2002;7(2):139-154. 
6. Omoto AM, Snyder M. Sustained helping without obligation: motivation, longevity of service, and perceived attitude change among AIDS volunteers. J Pers Soc Psychol. 1995;68(4): 671-686.

7. Clary EG, Snyder M, Ridge RD, et al. Understanding and assessing the motivations of volunteers: a functional approach. J Pers Soc Psychol. 1998;74(6):1516-1530.

8. Clary EG, Snyder M. The motivations to volunteer: theoretical and practical considerations. Curr Dir Psychol Sci. 1999;8(5): 156-159.

9. Planalp S, Trost M. Motivations of hospice volunteers. Am J Hosp Palliat Care. 2009;26(3):188-192.

10. Claxton-Oldfield S, Wasylkiw L, Mark M, Claxton-Oldfield J. The inventory of motivations for hospice palliative care volunteerism: a tool for recruitment and retention. Am J Hosp Palliat Care. 2011;28(1):35-43.

11. Garbay M, Gay MC, Claxton-Oldfield S. Motivations, death anxiety, and empathy in hospice volunteers in France. Am J Hosp Palliat Care. 2015;32(5):521-527.

12. Claxton-Oldfield S, Claxton-Oldfield J, Paulovic S, Wasylkiw L. A study of the motivations of British hospice volunteers. Am J Hosp Palliat Care. 2013;30(6):579-586.

13. Kolnick L, Mulder J. Strategies to improve recruitment of male volunteers in nonprofit agencies. Am J Hosp Palliat Care. 2007; 24(2):98-104.

14. Fletcher TD, Major DA. Medical students' motivations to volunteer: an examination of the nature of gender differences. Sex Roles. 2004;51(1):109-114.

15. Chapman J, Morley R. Collegiate service-learning. J Prev Interv Community. 1999;18(1):19-33.

16. Prentice DA, Carlsmith KM. Opinions and personality: on the psychological functions of attitudes and other valued possessions. In: Maio GR and Olson JM, eds. Why We Evaluate: Functions of Attitudes. Mahwah, NJ: Erlbaum; 2000:23-248.

17. Switzer CL, Switzer GE, Stukas AA, Baker CE. Medical student motivations to volunteer: gender differences and comparisons to other volunteers. J Prev Interv Community. 1999;18(1-2):53-64.

18. Eagly AH, Crowley M. Gender and helping behavior: a metaanalytic review of the social psychological literature. Psychol Bull. 1986;100(3):283-308.

19. Eagly AH, Wood W. Explaining sex differences in social behavior: a meta-analytic perspective. Pers Soc Psychol Bull. 1991; 17(3):306-315.

20. Eagly AH, Wood W, Diekman AB. Social role theory of sex differences and similarities: a current appraisal. In: Eckes T,
Trautner HM, eds. The Developmental Social Psychology of Gender. Mahwah, NJ: Lawrence Erlbaum; 2000: 123-174.

21. Eagly AH. The his and hers of prosocial behavior: an examination of the social psychology of gender. Am Psychol. 2009;64(8):644-658.

22. BMFSFJ. Monitor Voluntary Activities (No. 2). Volunteering in Germany 1999-2004-2009. Summary of the 3rd Survey on Volunteering. Berlin: Federal Ministry for Family Affairs, Senior Citizens, Women and Youth (BMFSFJ); 2010.

23. Auger J. Social Perspectives on Death and Dying. 2nd ed. Halifax, NS: Fernwood; 2007.

24. Einolf CJ. Gender differences in the correlates of volunteering and charitable giving. Nonprof Volunt Sect Q. 2010;40(6):1092-1112.

25. World Health Organization Process of Translation and Adaptation of Instruments. http://www.who.int/substance_abuse/research_ tools/translation/en/index.html. Accessed April 24, 2017.

26. EFS Survey [computer program]. Version 10.5. Köln, Germany: Questback GmbH; 2015.

27. Bierhoff HW, Schülken T, Hoof M. Skalen der Einstellungsstruktur ehrenamtlicher Helfer (SEEH) [Scales of the attitude structure of volunteers (SEEH)]. Z Personalpsychol. 2007;6(1):12-27.

28. RStudio: Integrated development environment for $R$ [computer program]. Version 3.3.1. Boston, MA: RStudio Inc; 2016.

29. Muthén LK, Muthén BO. Mplus User's Guide. 7th ed. Los Angeles, CA: Muthén \& Muthén; 1998-2012.

30. Marsh HW, Morin AJS, Parker PD, Kaur G. Exploratory structural equation modeling: an integration of the best features of exploratory and confirmatory factor analysis. Annu Rev Clin Psychol. 2014;10:85-110.

31. Terwee CB, Bot SD, de Boer MR, et al. Quality criteria were proposed for measurement properties of health status questionnaires. J Clin Epidemiol. 2007;60(1):34-42.

32. Silver CB. Gendered identities in old age: toward (de)gendering? J Aging Stud. 2003;17(4):379-397.

33. Baltes P, Smith J. Multilevel and systematic analyses of old age: theoretical and empirical evidence for a fourth age. In: Bengston V, Schaie KW, eds. Handbook of Theories of Aging. New York, NY: Springer; 1999.

34. Carstensen LL, Isaacowitz DM, Charles ST. Taking time seriously. A theory of socioemotional selectivity. Am Psychol. 1999;54(3):165-181.

35. Independent Sector. Giving and volunteering in the United States: Findings from a National Survey, 2001 edition. Washington, DC: Independent Sector; 2001.

36. Morrow-Howell N. Volunteering in later life: research frontiers. $J$ Gerontol B Psychol Sci Soc Sci. 2010;65(4):461-469. 